\title{
Exploration of Modern Apprenticeship in Automobile Repair Major in HigherVocational Education in China
}

\author{
Bai You-jun ${ }^{1, a}$, Zheng Yan $^{2}$ and Liu Shi-hao ${ }^{3}$ \\ ${ }^{1}$ College of Engineering and Technology, Hainan College of Economics and Business, Haikou, 571127, China \\ ${ }^{2}$ International Institute of Education, Hainan College of Economics and Business, Haikou, 571127, China \\ ${ }^{3}$ College of Mechanical and Electrical Engineering, Hainan University, Haikou, 570228, China
}

\begin{abstract}
Based on the current status of China's auto industry, it elaborates on the characteristics of modern Chinese apprenticeships and combines the importance of modern apprenticeships in the auto repair majors of vocational colleges. It finds out problems existing in current governments, companies, schools, teachers, and students, and proposes The solution provides a reference for the development of modern apprenticeships in China's vocational colleges.
\end{abstract}

\section{Introduction}

With the development of China's economy, vocational education has begun to adapt to it. In 2014, China began to propose modern apprenticeships. However, the development of modern Chinese modern apprenticeship has its own problems. the modern apprenticeship system of automobile repair major in higher vocational colleges is mainly studied in this article.

In 2017, China's auto production and sales completed 29.015 million vehicles and 28.887 million vehicles respectively, From 2009 to 2017, the production and sales volume of China's automobiles have ranked first in the world for nine consecutive years. Automobile has become common consumer goods into the family, with the continuous and rapid growth of car sales, the corresponding auto market is also booming. $4 \mathrm{~S}$ stores and automobile maintenance enterprises have produced a large amount of demand for automobile inspection and maintenance professionals. According to relevant statistics, there are more than 360 vocational colleges that have opened this speciality in China, but the education in most of these institutions tends to be theoretical. Although students have mastered solid theoretical knowledge, however, because of the lack of practical experience, low salary and many other reasons, it is difficult for a large number of professional students to meet the professional needs of the relevant posts in the enterprise.

\section{Modern apprenticeship in China}

China's modern apprenticeship system has achieved good results in the implementation of "modern

*Corresponding author: a 642baiyoujun $@ 163 . c o m$ apprenticeship" with reference to some developed countries in the West (such as Germany, Australia, etc.) in order to formulate a modern apprenticeship system for China's national conditions. Its characteristics are: "dual subject", "dual identity", "dual mentors", "double certificates". "Dual-subject" refers to the school and the enterprise's two main subjects jointly educating people; "dual identity" refers to the student's dual identity of the student and apprentice, "double tutor" refers to the teachers with strong professional basic knowledge, practical skills knowledge of relevant posts, and strong professional comprehensive practice ability, and advanced technical talents tutors with good teaching ability and experienced operation and practice ability. "double certificates" are academic certificates and vocational qualification certificates.

\section{The importance of modern apprenticeship in the major of auto repair}

\subsection{The modern apprenticeship system provides a new model for the cultivation of talents}

The modern apprenticeship system provides a new model for the cultivation of talents for our technical personnel. In the past, professional education in the automobile industry, the colleage was a major training place for students, to provide the main help for the development of students. However, with the development of society, traditional teaching methods have not adapted to the development of society today. Therefore, the modern apprenticeship system of school- 
enterprise cooperation provides a new training mode for the talented people in college. Through apprenticeship, students combine the theoretical knowledge learned with the social practice, constantly increase the students' practical experience, promote the overall development of the students, and in turn provides the school with a new talent training model.

\subsection{Improve the practical ability and professional level of the students}

The modern apprenticeship system improves the practical operation ability and professional level of students through school-enterprise cooperation. The apprenticeship system can improve students' practical ability and professional level by combining the theoretical knowledge with the social practice in the school by letting the students learn the repair skills with the teachers in the enterprise. By combining students with the development of society, the modern apprenticeship allows students to adapt themselves to the social development requirements during the school study, and improve themselves in the school and society, so as to provide the foundation for the future into the society. Therefore, the modern apprenticeship system continuously improves students' practical ability and professional level through social practice, and increases students' operating experience, thereby enhancing students' competitiveness.

\subsection{Make full use of social resources to achieve a win-win situation for schools and enterprises}

The modern apprenticeship system makes full use of social resources to combine school education with social education, so as to achieve a win-win situation between schools and enterprises. In the past school education, automobile repair major is always short of opportunities for students to practice, resulting in confusion and unease in entering the society. Modern apprenticeship connects students with the society, allowing students to learn through theory during the school, and then go to the company to follow the master to practice learning. In practice, not only exercise their own operating skills, but also improve their own professional standards. Therefore, the modern apprenticeship system uses the social resources to combine the advantages of the school and the enterprise, and ultimately achieves a win-win situation for both schools and enterprises.

\section{Problems existing in developing modern apprenticeship in China's auto major}

\subsection{The government pays insufficient attention to support}

The modern apprenticeship as a national vocational education and training system, which represented by a set of top-level design of the legal system, organization management, standard specification, supervision and certification, funding mechanism. The Ministry of education should work together with relevant departments to work out specific rules for implementation rather than vocational colleges as the main body. The governments at all levels do not pay enough attention and support to them.

\subsection{The enthusiasm of enterprises to participate is not high}

There is no effective mechanism guarantee for the cooperation between school and enterprise. The cost that the enterprise produces in the process of training the talents of the school has not been compensated. It also needs to provide the master, the field and the certain risk. The enthusiasm of enterprises to participate in school-enterprise cooperation is not high.

\subsection{Insufficient ability of teachers in higher vocational colleges}

There are few teachers in higher vocational colleges who have never engaged in the work of the auto repair industry, and have not studied the automobile repair in detail. The school has not fully realized the "integration of physical and practical" vocational colleges. Because of the high demand for the practical skills of the teachers, the auto technology is changing rapidly and rapidly, it is difficult for the some teachers who are lack of pratical skills to adapt with the development. Although the development of modern apprenticeship has provided more practical training opportunities for college teachers, to a certain extent, it has enhanced the level of practical skills of teachers, but the ability of some teachers still needs to be improved and the overall level of teachers is inadequate.

\subsection{Insufficient construction of training room and training factories in school}

Many vocational colleges are constrained by factors such as funds and venues, which results in a serious shortage of training rooms in schools and poor training conditions. Some institutions have only limited access to practical training sites, or only a few students can perform practical training. Constrained by the system, 
many schools are unable to build school-run enterprises such as auto repair shops and autocosmetic shops, making students lack a part of training conditions.

\subsection{Student's working literacy is not high}

Today's students are mainly the post-90s. These students do not have a high level of interest in learning. They generally lack the ability of self practice, and are unwilling to do so. They are afraid of being dirty and afraid of being tired.

\subsection{Unreasonable time for training courses}

Non-professional courses take up some time, such as application writing. Due to the constraints of school training conditions, theoretical courses take up more time, while practical training courses have very little time.

\section{Countermeasures for developing modern apprenticeship in automobile repair major in China}

\subsection{The government has increased its efforts}

The Ministry of education and other departments should formulate a reasonable policy plan for modern apprenticeship, provide corresponding policy support and fund support, so that enterprises can obtain preferential conditions such as capital support and tax relief through the modern apprenticeship system. Industry departments and associations should intensify their research efforts, giving full play to the advantages of the industry and exploring the characteristics of modern apprenticeship in the auto repair industry. For vocational colleges that have established modern apprenticeship, the government should support schools to set up enterprises without tax.

\subsection{Improve the enthusiasm of enterprises}

On the one hand, the government provides financial and policy support for enterprises. On the other hand, the government requires enterprises to undertake their obligations and require enterprises to participate in the development of students' modern apprenticeship. At the same time, a certain honor is granted to the enterprise, and the enterprise is recognized through the sense of honor.

\subsection{Improve teachers' ability}

The teachers of automobile repair specialty in higher vocational colleges are regularly carried out to the business line, and the examination is carried out by the enterprises, which will further improve the practical skills and enrich the work experience of the teachers. The training of the company's master chefs makes the company's masters better at the level of teaching.

\subsection{Reasonable construction of training rooms and school-run enterprises}

Increasing investment and building reasonable training rooms will make basic training better. For example, the construction of engine disassembly training room, chassis disassembly training room, gearbox disassembly training room, automotive electrical training room, etc. Establish school-run auto repair, auto cosmetology, and other companies, and employ highly experienced corporate personnel to work in school enterprises. We will conduct training on campus and establish an on-campus auto repair shop and a car beauty shop. So that students can directly learn about car repair, beauty, maintenance and other content.

\subsection{Resetting the curriculum system}

Resetting the curriculum system is another important measure for the implementation of modern apprenticeship. In the past social practice, students are basically in a business for half a year or so back to school to re - study, and then no more social practice. This way of school-enterprise cooperation will, to a certain extent, cause some harm to students' practical ability. In such a situation, the school delivers the semi-finished products to the society, rather than the real talents with social practice ability and operation experience. Therefore, in terms of the curriculum system, the school must break the traditional curriculum training system in the past, follow the direction of social development, continue to advance with the times, and adapt to the development of modern society, so as to promote the improvement of students' practical ability. This curriculum system should pay attention to the following several aspects. On the one hand, the school should improve the curriculum system according to the practice of students and the situation of enterprises. Making students change their traditional practice is just a form of walking. The curriculum system of automobile maintenance major should be arranged according to the technology and operation of enterprises to adapt to the development of students. On the other hand, the 
school's practice forms need to be flexible and changeable. Instead of the past half-year practice. It is necessary to carry out overall practical activities for students and allow them to use their spare time for practical activities. Using the combination of workintegrated learning and alternation of work and study, the transformation of the original curriculum system is a requirement of modern social practice. Therefore, in terms of curriculum system, schools should actively innovate and constantly adapt to the social requirements of development.

\subsection{Improve students' enthusiasm}

By setting up the curriculum, changing the form of teaching and other forms, such as setting up interesting contents, such as troubleshooting and training, fully mobilize the students' learning enthusiasm, so that students can better master auto repair skills.

\subsection{Establish a model of school-enterprise cooperation}

Establishing the teaching mode of school enterprise cooperation is an important prerequisite for the implementation of the modern apprenticeship system. In the modern apprenticeship system, we should connect the students with the society through the cooperation between school and enterprise, and then increase the students' social practice ability and increase the relationship between the students and the society. Therefore, the school-enterprise cooperation method is an important measure to implement the modern mentoring system. There are few employees in the automotive maintenance industry and they are highly fragmented. Therefore, schools must be cautious when choosing the cooperative enterprises. First, we must establish a school-enterprise cooperation. Schools can conduct surveys on the automobile maintenance industry based on the actual situation in the local area and select local companies with good reputation and good performance. Then let the relevant personnel of the school meet these car repair enterprises, and express the intention of school enterprise cooperation to the person in charge of the automobile maintenance enterprise. Or let the relevant person in charge of the automobile maintenance enterprise go to the school for inspection, and the two sides will discuss and exchange the school enterprise cooperation. In the end, both parties reached consensus on school-enterprise cooperation. After the two sides agree on the cooperation between school and enterprise, both sides should make clear provisions on the obligations and enjoyment of the rights of both sides in the process of cooperation between school and enterprise, divide the responsibilities of the two sides in the process of school enterprise cooperation, and then standardize them by rules and regulations, so as to ensure the smooth implementation of the cooperation between school and enterprise. Therefore, in the practical application of the modern apprenticeship system in automobile repair, the first thing to do is to establish a school-enterprise cooperation system.

\section{References}

1. TAN Yiping, WANG Guizhen. The Predicament and Countermeasures of Modern Apprenticeship System for Automobile Inspection and Maintenance Majors in Higher Vocational Colleges in China. Banaszak The Guide of Science \& Education, 55-57, 9 (2018)

2. ZHAO Yumei, ZHANG Ran. Modern Apprenticeship Practice in Automobile Maintenance Specialty of Higher Vocational College_-A Case Study of Tangshan Polytechnic College. Industrial Technology \& Vocational Education, 24-25, 14 (2016)

3. LIU Yuhong. Study on the Practice of ModernApprenticeship in the Higher Vocational Vehicle Repair Specialty. Industrial Technology \& Vocational Education, 23-25, 15 (2016)

4. JIA Wensheng, PAN Jianfeng, LIANG Ningsen. Construction of Modern Apprenticeship in Higher Vocational Colleges:the System Bottleneck and Strategies. Journal of East China Normal University(Educational Sciences),47-53, 1 (2017)

5. BIS.Department for Business,Innovation andSkills.Apprenticeships Evaluation:Employers, 34(2013)

6. National Apprenticeships Service ( NAS ) , Ap-prenticeship training agencies, 11( 2014) 